\title{
LEYES POLÍTICAS ESPAÑOLAS 1808-1978 (*)
}

\author{
Spanish Political Laws 1808-1978
}

ROBERTO L. BLANCO VALDÉS

¿Qué habría sido de la historia del constitucionalismo español sin la contribución fundamental que el profesor Varela Suances viene haciendo desde hace cuatro décadas a su estudio y mejor conocimiento? Pocos constitucionalistas e historiadores españoles tendrían dudas al respecto si fuesen requeridos para responder esta pregunta. Y es que, aunque los trabajos sobre nuestro pasado constitucional no comenzaron, desde luego, con las numerosas aportaciones del catedrático gallego, todas de indiscutible calidad, sin su dedicación prácticamente monográfica al análisis - constante, riguroso y lleno de talento- de la evolución de nuestro constitucionalismo hoy sabríamos sobre él, sin duda, mucho menos. Además de ello, y por si su obra científica no resultase, en sí misma, suficientemente significativa, Joaquín Varela se ha erigido por méritos propios en cabeza de un grupo de constitucionalistas asturianos que han seguido con brillantez el camino que él ha contribuido decisivamente a desbrozar. Las Leyes políticas españolas 1808-1978, que constituyen el objeto de este comentario, demuestran, por si tal cosa hiciera alguna falta, que no hace, esa doble dimensión de la aportación del profesor Varela Suances al avance de una parcela esencial de nuestro pasado, que ha condicionado en grandísima medida, y, como está bien a la vista, sigue haciéndolo, la vida política española: por un lado, la de riguroso historiador del constitucionalismo; por el otro, la de impulsor de esos estudios, bien dirigiendo la tesis doctorales de jóvenes investigadores, bien, como en este caso, coordinando ambiciosas obras colectivas.

(*) Joaquín VARela SuANCES-CARPegna (dir.) (2012-2015): Leyes políticas españolas 1808-1978, 5 vols., Iustel.

Revista Española de Derecho Constitucional

ISSN-L: 0211-5743, núm. 105, septiembre-diciembre (2015), págs. 389-392

http://dx.doi.org/10.18042/cepc/redc.105.13 
Pues una obra colectiva son estas Leyes politicas españolas 1808-1978; y una ambiciosa obra también, como enseguida hemos de ver. Bajo esa denominación genérica se agrupan en realidad cinco volúmenes, respectivamente titulados, en el mismo orden en que fueron publicados, Constitución y leyes fundamentales, editado por el propio Joaquín Varela Suances; Leyes y normas electorales en la historia constitucional española, del que se encargó Miguel Ángel Presno Linera; Reglamentos parlamentarios (1808-1977), preparado por Ignacio Fernández Sarasola; La Jefatura del Estado, el Gobierno y la Administración central, cuya edición asumió Clara Álvarez Alonso; y, finalmente, Derechos y Libertades, del que se hizo responsable Juan M. ${ }^{a}$ Bilbao Ubillos. La mera enumeración de los títulos de cada uno de esos cinco volúmenes da ya perfecta idea del amplísimo campo normativo que cubren en conjunto: las leyes constitucionales, la normativa electoral, la regulación de la vida parlamentaria, la organización del la jefatura del Estado y el poder ejecutivo y la regulación de las libertades y derechos. Es decir, las Constituciones y aquello que materialmente las conforman: la ordenación de los poderes del Estado y los derechos y libertades sin las que, como sabemos, desde que así lo formulara la francesa Declaración de Derechos del Hombre y del Ciudadano de 1789, no puede existir ninguna Constitución digna del tal nombre.

Cada uno de los volúmenes no se limita en todo caso, como suele ser frecuente, a recopilar normas, colocándolas una tras otra después del correspondiente índice (en ocasiones, ni eso) que deja constancia de la lista de las que han sido incluidas en sus páginas. Muy lejos de ello, esta magnífica y muy exhaustiva selección de las leyes políticas de España se concibe no sólo como una obra de consulta de las muchas disposiciones o proyectos normativos de distinto rango (Constituciones, leyes, Reales-Decretos, decretos, anteproyectos, proyectos de ley) que conforman los diferentes tomos en que aquélla, con muy buen criterio, se organiza sino también como un estudio de la materia a la que cada tomo se dedica. Por eso, todos ellos, del primero al último, se abren, primero, con un amplío estudio preliminar de sus respectivos editores y se organizan, después, con arreglo a una ordenación de las normas por períodos históricos. Sobre los estudios preliminares, y ante la obvia imposibilidad de referirse de forma individual a cada uno, es suficiente con destacar la alta calidad de todos ellos, como no podía ser de otra manera dada la cualificación de los responsables de los diferentes volúmenes, excelentes conocedores de la materia de la que respectivamente se hacen responsables. Su importancia procede, por lo demás, de un hecho obvio: que una recopilación de normas sin un estudio que las sitúe en su contexto, explique su evolución y destaque sus continuidades y discontinuidades es poco menos que un mero listado, útil quizá como obra de consulta 
para el especialista, pero de valía muy escasa para quien se acerca ella sin ser un estudioso de la materia de que se trata en cada caso.

En la importancia de la periodificación de las normas tampoco parece necesario insistir demasiado. Nuestra historia política no ha sido ni mucho menos lineal (digamos al modo de la británica, para entendernos) sino que se ha caracterizado, como es bien conocido, por constantes cambios de Constitución, por la alternancia de períodos constitucionales y de negación radical del constitucionalismo, por avances progresistas y retrocesos conservadores y, en suma, por la existencia de períodos bien definidos, que permiten organizar con orden, para entenderla mejor, una evolución política compleja como pocas: por eso distinguir el breve período de vigencia del Constitucionalismo revolucionario gaditano, los de negación del constitucionalismo bajo la monarquía fernandina, las monarquías constitucionales de 1837 y 1845, la revolución de 1868, la I y la II Repúblicas con el largo período intermedio de la Restauración, el franquismo y los momentos iniciales del actual período democrático que se abre con la transición puede resultar fundamental para colocar las diferentes normas recopiladas en su contexto histórico preciso, para entender la naturaleza de las que las antecedieron y las sucedieron y, en suma, para suministrar el lector los instrumentos necesarios que le permitan saber por qué una determinada disposición o uno u otro proyecto destinados a aprobarlas tienen la significación que tienen en un determinado momento de la historia política española. De cada norma suministra, además, el editor al lector la fuente de la que ha sido tomada, lo que permite a quien desee hacerlo consultarla allí de primera mano si tienen posibilidades de acceso a la fuente que se cita.

Todo lo apuntado haría, desde luego, de estas Leyes políticas españolas 1808-1978 que ahora, de nuevo gracias al gran esfuerzo de Iustel llegan a nosotros (y digo de nuevo recordando la excelente colección de nuestros textos constitucionales que, bajo la dirección de Miguel Artola, publicó en nueve volúmenes la misma editorial hace unos años) un trabajo muy notable y una obra de indiscutible utilidad. Porque hay un aspecto de uno y otra que, para terminar esta breve reseña, no quisiera dejar de comentar. Me refiero al ímprobo trabajo de búsqueda de normas que ha llevado a cabo el editor de cada uno de los volúmenes de la recopilación. Un trabajo que no sería exagerado afirmar se acerca de algún modo a lo que, si se me permite la expresión, podríamos denominar la arqueología jurídica, pues si las Constituciones son, claro está, de todos conocidas, no ocurre lo mismo ni de lejos con las normas infraconstitucionales, de muchas de las cuales no sabíamos nada o casi nada. Los utilísimos instrumentos informáticos de los que hoy disponemos, ayudados por los potentes buscadores que han convertido la red en algo verdaderamente manejable, nos permiten lle-

Revista Española de Derecho Constitucional

ISSN-L: 0211-5743, núm. 105, septiembre-diciembre (2015), págs. 389-392

http://dx.doi.org/10.18042/cepc/redc.105.13 
gar a lugares donde antes era impensable hacerlo sin salir del despacho de trabajo. Pero ni aun así es posible encontrar en la red lo que sencillamente no está en ella: allí figuran, desde luego, y en diversas páginas web, las Constituciones (sirva de ejemplo la absolutamente portentosa del Archivio delle Costituzione Storiche de la Universidad de Turín [http://www.dircost.unito.it/cs/indice_paesi. shtml] donde es posible consultar con gran utilidad cientos de textos constitucionales, aprobados entre finales del siglo XVIII y la actualidad en una cincuentena de países de diferentes áreas geográficas), pero no la inmensa mayoría de las normas o proyectos de normas que se recogen en los cinco volúmenes en que se organizan estas leyes políticas españolas. El trabajo de búsqueda en archivos de quienes las han elaborado resulta, por eso, merecedor de gran aplauso, pues una cosa es colocar en fila normas que son bien conocidas y otra muy distinto ir reconstruyendo cuidadosamente un inter normativo que se mantenía escondido hasta la fecha. Sacarlo a la luz, ordenarlo, estudiarlo y comentarlo es una ardua labor que exige mucha paciencia y dedicación, de esas que dan lugar a que del trabajo de unos pocos acabe por beneficiarse mucha gente.

Termino ya. El conocimiento de nuestra historia normativa constituye una parte fundamental del de nuestra historia política y, aún más, del de nuestra historia a secas. Tanta es su importancia que sin echar la vista a atrás no es posible, muchas veces, entender cabalmente el presente en que se vive, y más en un país que, como España, se ha quedado prendido en algunas coyunturas de su pasado como quien huyendo de un mal que se quiere superar se queda enganchado en los pinchos de espino de las alambradas que para hacerlo ha de saltar. Estas Leyes políticas españolas 1808-1978 atestiguan lo que es ya bien conocido — un pasado conflictivo y tormentoso, pleno de avances y descalabrostambién la viveza de quienes en diferentes momentos de su historia confiaron en las leyes para resolver sus atrancos y problemas. No es poca cosa, pues sin confianza en la ley, sin el respeto a la ley a través de la cual se expresa la voluntad general, sólo quedan las tinieblas.

Revista Española de Derecho Constitucional 